\title{
Learning English mediated by Kahoot: Insights from the Indonesian EFL instructors
}

\author{
Moh. Arif Mahbub \\ English Education Department, Faculty of Teacher Training and Education, \\ Universitas Islam Jember, Jawa Timur, Indonesia \\ moharifmahbub@uij.ac.id

\begin{abstract}
Now, EFL pedagogical practices have gradually transformed from traditional classrooms into digital learning. Within this context, mobile devices have now been considered as an auspicious medium for future learning. This study investigated how EFL instructors from different secondary education institutions viewed the in-class use of Kahoot in English-language classrooms. To this end, they were invited to fill a 13-items web-based questionnaire covering several categories: factual, behavioral, and attitudinal. Twenty-seven $(n=27)$ Indonesian EFL instructors in secondary education at both public and private high schools mostly located in East Java, Indonesia, voluntarily participated in this present study by completing the online survey. The results indicated that participants mostly demonstrated positive feelings toward the utilization of Kahoot in EFL classrooms. It showed that Kahoot was perceived as a promising software application to enhance the English-language learning process. To explore the effectiveness of this online game-based platform, more future-related research with large-scale participants in broader geographic regions should be carried out in this area.
\end{abstract}

Keywords: Kahoot in English classroom; Indonesian EFL instructors; gamification; classroom technology

How to cite this paper (in APA style): Mahbub, M. A. (2020). Learning English mediated by Kahoot: Insights from the Indonesian EFL instructors. Journal on English as a Foreign Language, 10(2), 246-267. https://doi.org/10.23971/jefl.v10i2.1917 
DOI: https://doi.org/10.23971/jefl.v10i2.1917

Copyright (C) 2020 THE AUTHOR(S). This article is distributed under a Creative

Commons Attribution-ShareAlike 4.0 International license.

Currently, the significant advancement of telecommunication technologies in educational contexts has gradually migrated the teaching-learning processes from traditional textbook-based lecturing (Tan \& Liu, 2016) or "chalk and talk" teaching (Licorish et al., 2018) to a new mode of learning with the ample opportunities to collaborate and sharing teaching-learning resources. In this way, the utilization of mobile devices for learning (M-learning) has become a vital component to settle this issue as it can serve enormous potential benefits in increasing the quality of instruction such as ubiquitous and collaborative learning environment (Crescente \& Lee, 2011; Heflin et al., 2017; KukulskaHulme \& Viberg, 2018), flexibility \& portability (Kumar \& Chand, 2019; Şad \& Göktaş, 2014; Zhonggen et al., 2019), cost-effectiveness and time-efficient (Alsswey \& Al-Samarraie, 2019), improving cognitive development, autonomous, and creativity (Pereira et al., 2019), as well as facilitating knowledge exchange and students' interactions (Al-Emran et al., 2016). In short, the evolution of teaching-learning process is shifted from traditional face to face (F2F) classroom to virtual environment.

In recent decades, M-learning, as a subcategory of e-learning (Basak et al., 2018, p. 192), has attracted an abundance of attention from many prominent scholars across the world for its substantial contribution to pedagogical practices in various contexts (Al-Emran et al., 2016; Hsu, 2013; Kumar \& Chand, 2019; Wang et al., 2012). In the same vein, in the realm of foreign language (FL) pedagogy, it has significant impacts on facilitating the learners in various competencies such as listening \& speaking (Ataeifar et al., 2019; Chen \& Chang, 2011; Hwang et al., 2015), reading (Chang \& Hsu, 2011; Lin et al., 2019), vocabulary (Lin et al., 2019; Mahdi, 2017; Ou-Yang \& Wu, 2017; Uz Bilgin \& Tokel, 2019), and grammar (Ghorbani \& Ebadi, 2020). It shows that M-Learning gradually become growing phenomena.

As the current students are primarily digital natives (Prensky, 2001a, 2001b), it is highly required for the instructors to be more sensitive to bridge the gaps between today's students and teaching-learning materials by creating a digital learning atmosphere in their classroom to accommodate their needs and habits. To remedy this problem, one of the most prominent instructional methods is through the gamification strategy. Researchers have acknowledged the values of gamification in influencing human behavior (Buckley \& Doyle, 
2016; Sailer \& Homner, 2020), promoting engagement (Brophy, 2015; Rahman et al., 2018), generating motivation (Deterding et al., 2011; Hwang et al., 2015; Persico et al., 2019), promoting attractive competition (Huang et al., 2018), providing spontaneous immediate feedback (Bouchrika et al., 2019; Koivisto \& Hamari, 2014), and enhancing students' learning achievement (Attali \& ArieliAttali, 2015; Buckley \& Doyle, 2016; Yıldırım \& Şen, 2019). Specifically, an enormous body of research has also indicated that game-based learning (GBL) instruction has significantly contributed to promoting students' language learning experience (Ataeifar et al., 2019; Klimova \& Kacetl, 2018; Lee et al., 2016; Lin \& Lin, 2019; Liu \& Chu, 2010; Ma, 2017). Therefore, it is the teacher challenges. If students are mostly tech-savvy, teachers' main responsibility is to adjust pedagogical practices.

To respond to this challenge, various mobile gamification apps with educational benefits have been invented for facilitating teaching-learning practices. One of the prominent applications invented is Kahoot that has become increasingly popular in educational areas for its easy-to-use and ability to enhance classroom dynamics (Esteves et al., 2017, p. 501; Plump \& LaRosa, 2017), increasing students' engagement, motivation, and concentration (Wang \& Tahir, 2020), as well as fostering critical thinking and communication (Hughes et al., 2018). Not surprisingly, statistics reported that approximately over 50 million users in over 180 countries played Kahoot (Kinder \& Kurz, 2018). Also, Kahoot allows the instructors to both introduce new concepts and assess to what extent the students master the materials through game-based quizzes in the forms of surveys, quizzes, and discussions with the high-quality of multimedia files displayed in great graphical resolution (Batsila \& Tsihouridis, 2018; Felszeghy et al., 2019; Ismail et al., 2019; Plump \& LaRosa, 2017; Tsihouridis et al., 2018).

Throughout recent years, many influential academics around the world have been interested in investigating Kahoot incorporated into a broad multidisciplinary context of the study (Esteves et al., 2017; Guardia et al., 2019; Ismail et al., 2019; Kinder \& Kurz, 2018; Lee et al., 2019; Martins et al., 2019; Rahman et al., 2018). Those all works of literature agree that Kahoot can potentially facilitate pedagogical practices. Nevertheless, while the abovementioned literature posits the positive results, several subsequent pieces of research revealed the contradictory findings. Numerous studies reported that the participants identified some downsides of the in-class use of not appearing questions in the mobile device, only choosing one answer, network connectivity, the time limit (Hadijah et al., 2020), and the appropriate devices 
(Criollo-C \& Luján-Mora, 2019; Wang \& Tahir, 2020). Empirical findings have claimed that Kahoot has constraints that it is only suitable for multiple-choice formats instead of essay questions (Ismail et al., 2019) and produces higherlevel anxiety among the students (Wang \& Tahir, 2020; Zarzycka-piskorz, 2016). Hence, there are still open issues to be explored in the realm of education.

Besides, those previous works have been situated in Europe (e.g. Austria, Portugal, and Spain), South America (e.g. Brazil), USA, and Asia (Malaysia, Thailand, Taiwan) focusing on various realms: engineering education, business management, medical education, computer science, vocabulary science, nursing, earth science, and information technology (networking). In the case of the EFL context, however, studies investigating the instructors' attitudes towards the utilization of Kahoot in Indonesia, particularly in secondary schools, are still in its infancy. Moreover, those studies mostly attempted to investigate the in-class use of Kahoot from the viewpoint of the students as the research participants. Thus, investigating the instructors' beliefs towards the inclass use of Kahoot is a very promising research topic since their beliefs will significantly affect the students' achievement as well (Baleghizadeh \& Shakouri, 2017). Therefore, it is highly necessary to do to strengthen the research gap.

For those reasons, it is highly required to explore the attitudes towards in-class use of Kahoot from the EFL instructors' perspectives. More specifically, this work is a response to a call for expanding empirical studies on in-class use of Kahoot from the viewpoint of EFL instructors situated in secondary education in Indonesia. The present research will contribute to providing empirical evidence that will enrich literature and inform practices on how instructors perceive in-class use of Kahoot in EFL settings. Furthermore, the results can provide constructive inputs for software developers to re-design this app for promoting more effective in-class usage of Kahoot in the EFL context. Thus, this study aimed at exploring in-depth EFL instructors' perceptions of the in-class use of Kahoot in secondary schools. Therefore, the overarching research question guiding in this study is, "What perceptions do the instructors have of the in-class use of Kahoot in EFL context as a tool teaching-learning?"

\section{METHOD}

\section{Research Design}

The current study employed a survey method (Ary et al., 2010; Berends, 2006; Fraenkel et al., 2012) aimed at exploring the characteristics of both individuals and groups. In this present study, the participants' beliefs, opinions,

Journal on English as a Foreign Language, 10(2), 246-267

p-ISSN 2088-1657; e-ISSN 2502-6615 
and behaviors were explored via web-based questionnaire using Google forms and then analyzed quantitatively using statistical software.

\section{Context and Participants}

For this study, a total of twenty-seven $(n=27)$ EFL teachers in secondary education at different high schools (Public $=44.4 \%$, Private $=56.6 \%$ ) mostly located in East Java, Indonesia, were chosen as participants based on a voluntary basis and their experience concerning the in-class use of Kahoot in their pedagogical practices. All participants complied with the requirement that they had used Kahoot regularly in their classrooms throughout the year 2019. The majority of research participants were female (59.3\%) and the remaining $40.7 \%$ were male. The age distribution of the participants was ranging between 25 and 51 years $(M=35.56, S D=6.38)$ teaching in secondary schools for 1 to 33 years. The majority of research participants were the English teachers with Bachelor's degrees and only seven teachers with a master's degree mostly majored in English Education or English Language and Literature. More specifically, all demographics and prior teaching information are perfectly reflected in Table 1 in more detail.

Table 1. Characteristics of the participants

\begin{tabular}{lc}
\hline \multicolumn{1}{c}{ Characteristics } & Percentage (\%) \\
\hline Gender & 40.7 \\
Male & 59.3 \\
Female & \\
Age Ranged & 62.9 \\
$25-35$ years & 29.7 \\
$36-45$ years & 7.2 \\
$46-56$ years & \\
Affiliation & 44.4 \\
Public Schools & 55.6 \\
Private Schools & \\
Teaching Experience & 66.7 \\
1 - 10 & 25.9 \\
11 - 20 & 3.7 \\
21 - 30 & 3.7 \\
More than 30 years & \\
Qualification & 74.1 \\
Bachelor's Degree & 25.9 \\
Master's Degree & \\
\hline
\end{tabular}

Journal on English as a Foreign Language, 10(2), 246-267

p-ISSN 2088-1657; e-ISSN 2502-6615 


\section{Instruments}

An anonymous web-based questionnaire was devised and distributed to all participants, following the guidelines of the standard procedures of the internet-based questionnaire suggested by Manfreda \& Vehovar (2008). Both the target population and cost-effectiveness became the major consideration for utilizing this online surveying (Vu \& Hoffman, 2011). Google Forms, one of the free online survey-creation tools, was employed for distributing this questionnaire as it served features to create a variety of question types as well as summarizing and visualizing the responses automatically in the form of tables, pie charts, and bar graphs (Murphy, 2018). Moreover, this web-based questionnaire was administered in the participants' native language, Bahasa Indonesia. It was comprised of two separate sections with different response format (Open-ended questions and Likert-type) consisted of factual (e.g. respondents' demographic characteristics), behavioral (e.g. in-class use of mobile devices), and attitudinal (e.g. attitudes towards in-class use of Kahoot) question (Dörnyei \& Taguchi, 2010, p. 5). The first section was designed for gathering the data concerning the participants' biographical profile (i.e., gender, age, affiliation, teaching experience, and educational attainment). In section 2, the researcher developed a 5-point Likert Scale response format questionnaire ranging from ' 1 ' for strongly disagree to ' 5 ' for strongly agree.

Moreover, the second section of questionnaire initially comprised 21 items mainly adopted and modified from several previous studies (Batsila \& Tsihouridis, 2018; Chen, 2016; Esteves et al., 2017; Gani et al., 2016; Georgieva et al., 2011; Licorish et al., 2018), with the following domains: instructors' perceptions regarding M-learning, and the Implementation of Kahoot in EFL classroom. Part 1 of the questionnaire consisted of 7 statements gathering information about instructors' beliefs about their preference to use M-learning compared to traditional courses as well as their M-learning experiences inside and outside classrooms. Part 2 consisted of 14 statements investigating instructors' views about the in-class of Kahoot in the EFL context focused mainly on the aspect of the enjoyment of playing, interaction among instructors and students, learning motivation, learning engagement, students' learning experience, and recommendation to use Kahoot more often in class.

Before administering this instrument to participants, several experts specializing in both ELT field and technology-assisted instructions were also involved to evaluate the content validity of the initial items of this instrument. Some of the irrelevant items were then deleted based on their reviews,

Journal on English as a Foreign Language, 10(2), 246-267

p-ISSN 2088-1657; e-ISSN 2502-6615 
feedbacks, and comments. Besides, some minor modifications concerning inappropriate diction used in some statements (items 5, 6, 10,11, and 13) were made for the sake of clarity. After the review and modifications, to validate the initial results of this instrument, it was piloted with a sample (9 experienced EFL Instructors). They did not involve as participants in the main study.

After piloting the instrument, a final 13-items web-based survey questionnaire was created for the main study including these following broad categories into mobile learning integration in EFL context (Item 1 - 3), teachers'-students' interaction and collaboration (Item $4-5$ ), the enjoyment of competition (Item 6), the enjoyment of playing (Items $7-8$ ), English learning motivation (Item 9), level of concentration (item 10), perceived learning experience (Item 11 and 12), and recommendation to use Kahoot in class (Item 13). These final survey items were re-administered three weeks later to the different group of EFL instructors in secondary schools.

\section{Data Collection}

As been mentioned earlier, the final survey questionnaire comprised 5 open-ended items collecting the data about the participants' demographic data and 13 items exploring the participants' views about the in-class use of Kahoot in EFL classroom. To collect the participants' responses, Google Forms was employed to conduct the survey. In so doing, a web link was created and posted it on a social media platform. Over a period of approximately two weeks, 27 participants voluntarily responded the survey. The data gathered from the questionnaire were stored in a spreadsheet.

\section{Data Analysis}

The quantitative data resulted from participants' responses on webbased questionnaires were re-evaluated using descriptive statistics presented as frequencies, percentages, means, and Standard Deviation (SD). To analyze the data, the researcher employed the software analysis program, SPSS v.20. Also, the internal consistency reliability of the instrument was analyzed using the Cronbach's Alpha coefficient, which was 0.814, signaling a highly reliable internal consistency (Cohen et al., 2007, p. 506).

Journal on English as a Foreign Language, 10(2), 246-267

p-ISSN 2088-1657; e-ISSN 2502-6615 


\section{FINDINGS}

\section{Participants' Perspectives on the Adoption of Mobile Learning}

The participants were asked to demonstrate which of the two options they prefer regarding M-learning or traditional face-to-face teaching. There were slightly over half of the participants $(n=16,59.2 \%)$ claimed that they preferred M-learning than traditional face-to-face learning environments. There were $33.3 \%(n=9)$ participants acclaimed indecisive options $(\mathrm{M}=3.67, \mathrm{SD}=$ 1.07). In response to the second statement, a clear majority of participants $(n=$ $22,81.4 \%$ ) admitted that M-learning is more interesting than the traditional classroom, while four $(14.8 \%)$ participants showed neutral responses and only $3.7 \%$ expressed disagreement $(\mathrm{M}=4.11, \mathrm{SD}=0.93)$. Meanwhile, $18(66.6 \%)$ participants agreed with the item 3, while neutral responses showed $29.6 \%$ ( $\mathrm{n}=$ 11 ) and only $3.7 \%(n=1)$ disagreement response $(\mathrm{M}=4.3, \mathrm{SD}=0.62)$. An overview of participants' responses to statements $1-3$ is presented in Table 2.

Table 2. Teachers' perceptions of M-learning

\begin{tabular}{|c|c|c|c|c|c|c|c|c|}
\hline Item & Statement(s) & $\begin{array}{l}\text { SD } \\
(\%)\end{array}$ & $\begin{array}{c}\mathrm{D} \\
(\%)\end{array}$ & $\begin{array}{c}\mathrm{N} \\
(\%)\end{array}$ & $\begin{array}{c}A \\
(\%)\end{array}$ & $\begin{array}{l}\text { SA } \\
(\%)\end{array}$ & M & $\begin{array}{c}\text { Std. } \\
\text { D }\end{array}$ \\
\hline 1 & $\begin{array}{l}\text { Preference between M- } \\
\text { learning and traditional } \\
\text { face-to-face learning. }\end{array}$ & $\begin{array}{c}7.4 \\
(n=2)\end{array}$ & & $\begin{array}{c}33.3 \\
(n=9)\end{array}$ & $\begin{array}{c}37 \\
(n=10)\end{array}$ & $\begin{array}{c}22.2 \\
(n=6)\end{array}$ & 3.67 & 1.07 \\
\hline 2 & $\begin{array}{l}\text { M-Learning is easier } \\
\text { and more interesting } \\
\text { than traditional courses. }\end{array}$ & $\begin{array}{c}3.7 \\
(n=1)\end{array}$ & & $\begin{array}{c}14.8 \\
(n=4)\end{array}$ & $\begin{array}{c}44.4 \\
(n=12)\end{array}$ & $\begin{array}{c}37 \\
(n=10)\end{array}$ & 4.11 & 0.93 \\
\hline 3 & $\begin{array}{l}\text { The importance of } \\
\text { using smartphones or } \\
\text { tablets for language } \\
\text { learning. }\end{array}$ & & $\begin{array}{c}3.7 \\
(n=1)\end{array}$ & $\begin{array}{c}29.6 \\
(n=8)\end{array}$ & $\begin{array}{c}40.7 \\
(n=11)\end{array}$ & $\begin{array}{c}25.9 \\
(n=7)\end{array}$ & 4.30 & 0.62 \\
\hline
\end{tabular}

Note: SD: Strongly disagree, D: Disagree, N: neutral, SA: Strongly agree, A: Agree, M: Mean, Std. D: Standard Deviation.

\section{Participants' Feedback on the in-class Use of Kahoot}

\section{Classroom dynamics}

The next aspects were concerning classroom dynamics including classroom teacher-student interactions and collaborations (Item 4 \& 5), the enjoyment of competition (Item 6), and the enjoyment of playing (Item $7 \& 8$ ). Table 3 illustrates the results. Based on the results of the fourth statement, almost all participants $(n=26 ; 96.3 \%)$ reported that Kahoot could foster twoway interactions among teachers and students; the remaining responses were 
only $3.7 \%(n=1)$. Similarly, findings from the analysis on item 5 revealed that nearly all participants $(n=25 ; 92.6 \%)$ agreed that Kahoot could cultivate collaboration among them; as for the remaining responses revealed $7.4 \%(n=1)$ for indecisive responses. When responding the item 6 , the vast majority of participants $(n=24 ; 88.9 \%)$ confessed that they enjoyed the competitive environment in the Kahoot session. In light of the enjoyment of playing (item 7), $25(92.5 \%)$ participants admitted that they were passionately engaged while playing with Kahoot; $7.4 \%$ of participants expressed neutral responses. For item 8 , almost all participants ( $n=26 ; 96.3 \%$ ) expressed positive feelings that Kahoot could create a more fun and interactive learning atmosphere. Besides, along with the seventh statement, the mean score of the eighth statement was the highest compared to other statements $(\mathrm{M}=4.37, \mathrm{SD}=0.56)$.

Table 3. Participants' perceptions of Kahoot on classroom dynamics

\begin{tabular}{|c|c|c|c|c|c|c|c|c|}
\hline Item & Statement & $\begin{array}{l}\text { SD } \\
(\%)\end{array}$ & $\begin{array}{c}\mathrm{D} \\
(\%)\end{array}$ & $\begin{array}{l}\mathrm{N} \\
(\%)\end{array}$ & $\begin{array}{c}\mathrm{A} \\
(\%)\end{array}$ & $\begin{array}{l}\text { SA } \\
(\%)\end{array}$ & M & $\begin{array}{c}\text { Std. } \\
\text { D }\end{array}$ \\
\hline 4 & $\begin{array}{l}\text { Kahoot game in fostering } \\
\text { both student/students } \\
\text { and teacher/student } \\
\text { interaction. }\end{array}$ & & $\begin{array}{c}3.7 \\
(\mathrm{n}=1)\end{array}$ & & $\begin{array}{c}51.9 \\
(\mathrm{n}=14)\end{array}$ & $\begin{array}{c}44.4 \\
(\mathrm{n}=12)\end{array}$ & 4.3 & 0.68 \\
\hline 5 & $\begin{array}{l}\text { Kahoot in promoting } \\
\text { students' collaboration. }\end{array}$ & & & $\begin{array}{c}7.4 \\
(n=2)\end{array}$ & $\begin{array}{c}51.9 \\
(\mathrm{n}=14)\end{array}$ & $\begin{array}{c}40.7 \\
(n=11)\end{array}$ & 4.3 & 0.62 \\
\hline 6 & $\begin{array}{l}\text { I like the competitive } \\
\text { element in the Kahoot } \\
\text { session. }\end{array}$ & & & $\begin{array}{l}11.1 \\
(n=3)\end{array}$ & $\begin{array}{c}55.6 \\
(n=15)\end{array}$ & $\begin{array}{c}33.3 \\
(n=9)\end{array}$ & 4.22 & 0.64 \\
\hline 7 & $\begin{array}{l}\text { My students were } \\
\text { passionately engaged } \\
\text { while playing. }\end{array}$ & & & $\begin{array}{c}7.4 \\
(\mathrm{n}=2)\end{array}$ & $\begin{array}{c}48.1 \\
(n=13)\end{array}$ & $\begin{array}{c}44.4 \\
(\mathrm{n}=12)\end{array}$ & 4.37 & 0.62 \\
\hline 8 & $\begin{array}{l}\text { Kahoot session made the } \\
\text { class more fun and } \\
\text { interactive. }\end{array}$ & & & $\begin{array}{c}3.7 \\
(\mathrm{n}=1)\end{array}$ & $\begin{array}{c}55.6 \\
(n=15)\end{array}$ & $\begin{array}{c}40.7 \\
(n=11)\end{array}$ & 4.37 & 0.56 \\
\hline
\end{tabular}

\section{Motivation and perceived learning experience}

For item 9, a vast majority of participants $(n=24 ; 88.9 \%)$ reported that Kahoot promoted the students' learning motivation, whereas only a small percentage of responses $(n=3 ; 11.1 \%)$ expressed neutral answers. The survey also asked the participants, 'My students will be more attentive during the Kahoot session.' As expected, 25 (96.2\%) participants strongly agreed or agreed with the statement; while the rest $(n=2 ; 7.4 \%)$ chose indecisive options. For item 11, the analysis reported that 22 of the 27 participants admitted that Kahoot facilitated their students' learning experience on the subject taught; only five participants 
(18.5\%) reported neutral answers. Regarding the effects of Kahoot's session on students' academic performances, of the 27 responses, more than half the participants $(n=14 ; 51.8 \%)$ felt that Kahoot facilitated their students' academic achievements. Interestingly, 13 participants (48.1\%) opted to express neutral answers. For the thirteenth statement, the majority of participants ( $n=19$; $70.3 \%$ ) agreed that they recommended Kahoot to be implemented more often in class. As for the remaining responses, five participants $(18.5 \%)$ expressed neutral responses and only a small percentage $(n=3 ; 11.1 \%)$ opted to express negative feelings. Table 4 depicts the results of item $9-13$.

Table 4. Participants' views on aspects of motivation and perceived learning

\begin{tabular}{|c|c|c|c|c|c|c|c|c|}
\hline Item & Statement & $\begin{array}{l}\text { SD } \\
(\%)\end{array}$ & $\begin{array}{c}\mathrm{D} \\
(\%)\end{array}$ & $\begin{array}{c}\mathrm{N} \\
(\%)\end{array}$ & $\begin{array}{c}\mathrm{A} \\
(\%)\end{array}$ & $\begin{array}{l}\text { SA } \\
(\%)\end{array}$ & $\mathrm{M}$ & $\begin{array}{c}\text { Std. } \\
\text { D }\end{array}$ \\
\hline 9 & $\begin{array}{l}\text { Kahoot game increases } \\
\text { the students' } \\
\text { motivation. }\end{array}$ & & & $\begin{array}{c}11.1 \\
(n=3)\end{array}$ & $\begin{array}{c}55.6 \\
(n=15)\end{array}$ & $\begin{array}{c}33.3 \\
(n=9)\end{array}$ & 4.22 & 0.64 \\
\hline 10 & $\begin{array}{l}\text { My students will be } \\
\text { more attentive during } \\
\text { the Kahoot session. }\end{array}$ & & & $\begin{array}{c}7.4 \\
(n=2)\end{array}$ & $\begin{array}{c}55.6 \\
(n=15)\end{array}$ & $\begin{array}{c}37 \\
(n=10)\end{array}$ & 4.29 & 0.60 \\
\hline 11 & $\begin{array}{l}\text { Kahoot game } \\
\text { facilitates my } \\
\text { students' learning } \\
\text { experience on the } \\
\text { subject. }\end{array}$ & & & $\begin{array}{c}18.5 \\
(n=5)\end{array}$ & $\begin{array}{c}63 \\
(n=17)\end{array}$ & $\begin{array}{c}18.5 \\
(n=5)\end{array}$ & 4.00 & 0.62 \\
\hline 12 & $\begin{array}{l}\text { Kahoot's session } \\
\text { improves my students' } \\
\text { academic } \\
\text { performance. }\end{array}$ & & & $\begin{array}{c}48.1 \\
(n=13)\end{array}$ & $\begin{array}{c}40.7 \\
(n=11)\end{array}$ & $\begin{array}{c}11.1 \\
(n=3)\end{array}$ & 3.62 & 0.68 \\
\hline 13 & $\begin{array}{l}\text { I recommend Kahoot } \\
\text { to be used more often } \\
\text { in class. }\end{array}$ & $\begin{array}{c}3.7 \\
(\mathrm{n}=1)\end{array}$ & $\begin{array}{c}7.4 \\
(\mathrm{n}=2)\end{array}$ & $\begin{array}{c}18.5 \\
(n=5)\end{array}$ & $\begin{array}{c}40.7 \\
(n=11)\end{array}$ & $\begin{array}{c}29.6 \\
(n=8)\end{array}$ & 3.85 & 1.06 \\
\hline
\end{tabular}

\section{DISCUSSION}

This current study aims to provide an in-depth description of EFL instructors' perceptions of the in-class use of Kahoot in secondary schools. Overall, the findings demonstrated the positive responses concerning Kahoot integration into the EFL classroom on the aspects of classroom dynamics, motivation, and perceived learning experience. The empirical data resulted from the analysis on statement 1 indicated that participants arrive at a common consensus that they indicate a slight preference for choosing M-learning as they 
believe that it can increase the quality of traditional classrooms. These findings contribute to the empirical shreds of evidence resulted from previous researches (Chen, 2016; Georgieva et al., 2011), in which the participants opted for M-learning rather than conventional "chalk and talk" instructions. This may due to the opportunities offered by M-learning in terms of facilitating ubiquitous learning access.

For the second statement, based on the response rate, it is sensible to assume that the participants feel that learning English through mobile lessons is easier and interesting compared to the conventional face-to-face classroom. These results reflect that they acknowledge the benefits of M-learning as its quality to develop more attractive online learning environments rather than traditional teaching-learning pedagogy. The findings of the research concur with recent studies (Al-Hunaiyyan et al., 2018; Chen, 2016) which appreciated M-learning as an attractive learning tool. This may due to its values to offer plenty of opportunities for various ways of learning including promoting collaborative learning among the students and allowing them to have the connectivity to the outside world to acquire authentic learning contents from various learning resources.

In soliciting instructors' views on the importance of using mobile devices for language-learning, more than two-thirds of participants agree with the adoption of smartphones for pedagogical practices. Meanwhile, almost onethird of responses select neutral options meaning that they demonstrate indecisive responses indicating not everything about the in-class use of smartphones would be beneficial for their learning process, whereas a small percentage of participants demonstrate negative responses. The findings of the research contribute to previous works (Al-Hunaiyyan et al., 2018; Luís, 2018), in that mobile devices are crucially important to be imposed in their teachinglearning scenarios as they have a considerable impact on their teaching-learning process due to their ability to bring more attractive and interactive learning environments.

The results of the analysis on item 4 significantly proved that there is convincing evidence of a very high level of agreement (96.3\%) on Kahoot integration in terms of fostering students-teachers interactivity. This data suggests that this platform is perceived as a promising tool to support both teachers and students to strengthen greater communication among them. This finding is in line with several recent literature (Ismail et al., 2019; Licorish et al., 2018; Wang, 2015), in which Kahoot can enable social connectivity among them.

Journal on English as a Foreign Language, 10(2), 246-267

p-ISSN 2088-1657; e-ISSN 2502-6615 
As Kahoot can foster collaborative learning, of twenty-seven participants, twenty-five (92.6\%) participants acknowledged that this app can create the opportunity for collaborative learning in the classroom, which supported the previous researches (Baszuk \& Heath, 2020; Esteves et al., 2017).

In the light of competitive elements, 24 out of 27 participants (88.9\%) participants appreciated the competitive learning atmosphere in Kahoot session. This data suggests that Kahoot can create an energetic competitive environment (Baszuk \& Heath, 2020) through a game-like learning experience that can considerably affect students' learning. This empirical data confirmed the work of several previous studies (Baszuk \& Heath, 2020; Gani et al., 2016; Guardia et al., 2019; Licorish et al., 2018; Martins et al., 2019; Mu \& Paparas, 2015; Wang, 2015; Wang \& Lieberoth, 2016), which also resulted that the participants enjoyed the competitive elements in Kahoot session. On the contrary, some existing literature reported contradictory findings that the students were not enjoyable with the competitive element in the Kahoot system and the teachers felt anxious that this competitive gaming element made the students experienced anxiety during the Kahoot session (Baydas \& Cicek, 2019; Zarzycka-piskorz, 2016).

Regarding the enjoyment of playing, nearly all responses (92.5\%) concluded that they were more passionately engaged while playing with Kahoot in the classroom setting, which is in line with previous works (Baszuk \& Heath, 2020; Bawa, 2018; Baydas \& Cicek, 2019; Lauermann \& Barbosa, 2018; Wang, 2015). Similarly, responses on item 8 indicated that the majority of participants (96.3\%) confessed this platform could create more entertaining and interactive learning environments. This finding substantiates previous recent literature (Baydas \& Cicek, 2019; Wang, 2015; Wang \& Lieberoth, 2016; Wang \& Tahir, 2020), in saying that Kahoot can provide more interactive components in the classroom.

When asked to respond the item 9, participants believe that Kahoot game-based environment significantly affected the students' learning motivation levels. This result illustrated consistency with the research findings of other contemporary researches (Batsila \& Tsihouridis, 2018; Bawa, 2018; Baydas \& Cicek, 2019; Esteves et al., 2017; Guardia et al., 2019; Hou, 2018; Jones et al., 2019; Lauermann \& Barbosa, 2018; Licorish et al., 2018; Wang, 2015; Wang \& Lieberoth, 2016; Wang \& Tahir, 2020) confirming that the Kahoot session positively influenced the motivation levels of the students. However, when

Journal on English as a Foreign Language, 10(2), 246-267

p-ISSN 2088-1657; e-ISSN 2502-6615 
using Kahoot, one should seriously consider how to create well-designed questions. Otherwise, it can demotivate students indeed.

Furthermore, participants expressed overwhelming agreement $(92.6 \%)$ in responding to item 10 . This data imply that they witnessed this game-like quiz platform as a powerful application in maintaining the students' focus and enthusiasm. This current finding corroborates the findings resulted from many previous studies (Esteves et al., 2017; Gani et al., 2016; Mu \& Paparas, 2015; Wang \& Lieberoth, 2016; Wang \& Tahir, 2020), in which they acknowledged the benefits of Kahoot for the students in terms of keeping them to stay focused on the task. However, the gamified elements served by Kahoot such as points and leaderboard can be considered as the adverse effects as it can also turn their focus to the learning contents, as also found in Baydas and Cicek (2019). Hence, the instructor(s) should provide immediate feedback and check the students' understanding after each question to ensure efficient learning.

Item $11 \& 12$ are about how the instructors perceived the use of Kahoot in enriching learners' experience. As presented in table 3, a vast majority participant ( $81.48 \%$, versus only $18.5 \%$ who expressed negative responses) admitted that Kahoot activities assisted their students' understandings. This finding corresponds to initial literature (Baszuk \& Heath, 2020; Esteves et al., 2017; Jones et al., 2019; Licorish et al., 2018) which confirm that Kahoot creates the opportunity to assist the students' conceptual understanding about the topics given. For the twelfth statement, the data indicated that more than half of the participants $(n=14,51.8 \%)$ agreed that Kahoot significantly affected their students' learning performance, which is higher than $48.1 \%$ of those participants who expressed uncertain responses. This finding supports previously documented literature (Baszuk \& Heath, 2020; Bawa, 2018; Tsihouridis et al., 2018; Wang \& Tahir, 2020) that claimed Kahoot plays a significant role in increasing students' knowledge retention. Concerning the Kahoot recommendation, $70.3 \%$ acclaimed that they suggested Kahoot be incorporated more often in teaching-learning processes, which is significantly higher than neutral responses $(18.5 \%)$ and $11.1 \%$ of those who expressed disagreement. These participants' responses confirmed several past studies (Baszuk \& Heath, 2020; Esteves et al., 2017; Gani et al., 2016; Guardia et al., 2019; Plump \& LaRosa, 2017), which also indicated a strong agreement to recommend this platform to be implemented more often in pedagogical practices.

In general, viewing from this current study's findings, it can be strongly indicated that Kahoot offers enormous potential benefits for teaching-learning

Journal on English as a Foreign Language, 10(2), 246-267

p-ISSN 2088-1657; e-ISSN 2502-6615 
processes. However, the teachers should also consider how to integrate this tool properly to create and develop meaningful learning for their students. Since it has huge impacts on students' engagement, motivation, social interaction, and attention, it is the teachers' main responsibility to re-conceptualize of how it is going to be integrated to effectively stimulate the students' knowledge construction.

\section{CONCLUSION}

As been mentioned earlier, this present study was set out to answer the research question about the instructors' views on Kahoot integration into the EFL classroom at the secondary education level. Overall, after performing careful analyses on the data gathered from the web-based questionnaire, it was clear that the findings provide strong indications that the participants had a high-level acceptance perceiving Kahoot as the promising software application to enhance the English-language learning process. To be more specific, they mostly thought that it could generate positive energy having noticeable effects on classroom dynamics, generating the students' interest and concentration, as well as learning performance. However, notable inherent limitations should be taken into considerations as well. First, the participants voluntarily involved in this study were very limited $(n=27)$. Hence, there is an essential requirement to carry out large-scale research. Second, the data gathered in this study do not cover a wide geographical area as it involves the participants mostly located in the eastern regions of Java, Indonesia. Future researchers could revolve around investigating the EFL instructors' teaching experience using Kahoot in multiple institutions in different geographical regions so that the more accurate representation of data would be achieved. Third, since this study investigated the EFL instructors' perceptions in secondary schools setting, the findings could not be generalized to other settings in different levels of education. The perspectives of EFL university instructors remain under-researched. Further study could, therefore, focus on investigating EFL instructors at higher education level. Investigating Kahoot from the lecturers' standpoint would also be crucial for developing as well as designing digital game-based oriented teaching practices.

\section{ACKNOWLEDGEMENTS}

This research received national research funding from the Ministry of Research, Technology and Higher Education through the Directorate of Research and Community Services (DRPM) Indonesia, on Penelitian Dosen Pemula (2019)

Journal on English as a Foreign Language, 10(2), 246-267

p-ISSN 2088-1657; e-ISSN 2502-6615 
scheme. Also, the author would like to express his gratitude to the editor(s) and anonymous reviewer(s) for their constructive inputs on this manuscript.

\section{REFERENCES}

Al-Emran, M., Elsherif, H. M., \& Shaalan, K. (2016). Investigating attitudes towards the use of mobile learning in higher education. Computers in Human Behavior, 56, 93-102. https://doi.org/10.1016/1.chb.2015.11.033

Al-Hunaiyyan, A., Alhajri, R. A., \& Al-Sharhan, S. (2018). Perceptions and challenges of mobile learning in Kuwait. Journal of King Saud University Computer and Information Sciences, 30(2), 279-289. https://doi.org/10.1016/j.jksuci.2016.12.001

Alsswey, A., \& Al-Samarraie, H. (2019). M-learning adoption in the Arab gulf countries: A systematic review of factors and challenges. Education and Information Technologies, 24(5), 3163-3176. https://doi.org/10.1007/s10639019-09923-1

Ary, D., Jacobs, L. C., Sorensen, C., \& Razavieh, A. (2010). Introduction to research in education (8th ed.). Wadsworth, Cengage Learning.

Ataeifar, F., Sadighi, F., Bagheri, M. S., \& Behjat, F. (2019). Iranian female students' perceptions of the impact of mobile-assisted instruction on their English speaking skill. Cogent Education, 6(1), 1-19. https://doi.org/10.1080/2331186X.2019.1662594

Attali, Y., \& Arieli-Attali, M. (2015). Gamification in assessment: Do points affect test performance? Computers and Education, 83, 57-63. https://doi.org/10.1016/.compedu.2014.12.012

Baleghizadeh, S., \& Shakouri, M. (2017). Investigating the relationship between teaching styles and teacher self-efficacy among some Iranian ESP university instructors. Innovations in Education and Teaching International, 54(4), 394-402. https://doi.org/10.1080/14703297.2015.1087329

Basak, S. K., Wotto, M., \& Bélanger, P. (2018). E-learning, M-learning and Dlearning: Conceptual definition and comparative analysis. E-Learning and Digital Media, 15(4), 191-216. https://doi.org/10.1177/2042753018785180

Baszuk, P. A., \& Heath, M. L. (2020). Using Kahoot! to increase exam scores and engagement. Journal of Education for Business, 1-5. https://doi.org/10.1080/08832323.2019.1707752

Batsila, M., \& Tsihouridis, C. (2018). "Let's go... Kahooting" - Teachers' views on C.R.S. for teaching purposes. In M. E. Auer, D. Guralnick, \& I. Slmonks (Eds.), Teaching and Learning in a Digital World. The 20th International Conference on Interactive Collaborative Learning 2017 (pp. 563571). Springer International Publishing. https://doi.org/10.1007 /978-3-319- 
73210-7

Bawa, P. (2018). Using Kahoot to inspire. Journal of Educational Technology Systems, 47(3), 1-18. https://doi.org/10.1177/0047239518804173

Baydas, O., \& Cicek, M. (2019). The examination of the gamification process in undergraduate education: A scale development study. Technology, Pedagogy and Education, 28(3), 1-17. https://doi.org/10.1080/1475939X.2019.1580609

Berends, M. (2006). Survey methods in educational research. In J. L. Green, G. Camili, P. B. Elmore, A. Skukauskaiti, \& E. Grace (Eds.), Handbook of complementary methods in education research (pp. 1-865). Lawrence Erlbaum Associates.

Bouchrika, I., Harrati, N., Wanick, V., \& Wills, G. (2019). Exploring the impact of gamification on student engagement and involvement with e-learning systems. Interactive Learning Environments, 1-14. https://doi.org/10.1080/10494820.2019.1623267

Brophy, K. (2015). Gamification and mobile teaching and learning. In Y. (Aimee) Zhang (Ed.), Handbook of Mobile Teaching and Learning (pp. 91105). Springer-Verlag Berlin Heidelberg. https://doi.org/10.1007 978-3642-54146-9

Buckley, P., \& Doyle, E. (2016). Gamification and student motivation. Interactive Learning Environments, 24(6), 1162-1175. https://doi.org/10.1080/10494820.2014.964263

Chang, C. K., \& Hsu, C. K. (2011). A mobile-assisted synchronously collaborative translation-annotation system for english as a foreign language (EFL) reading comprehension. Computer Assisted Language Learning , 24(2), 155-180. https://doi.org/10.1080/09588221.2010.536952

Chen, I. J., \& Chang, C. C. (2011). Content presentation modes in mobile language listening tasks: English proficiency as a moderator. Computer Assisted Language Learning, 24(5), 451-470. https://doi.org/10.1080/09588221.2011.577749

Chen, K. T. (2016). Examining EFL instructors' and students' perceptions and acceptance toward M-learning in higher education. Universal Access in the Information Society, 16(4), 967-976. https://doi.org/10.1007/s10209-0160494-8

Cohen, L., Manion, L., \& Morrison, K. (2007). Research methods in education (6th ed.). Routledge.

Crescente, M. L., \& Lee, D. (2011). Critical issues of m-learning: Design models, adoption processes, and future trends. Journal of the Chinese Institute of Industrial Engineers, 28(2), 111-123. 
https://doi.org/10.1080/10170669.2010.548856

Criollo-C, S., \& Luján-Mora, S. (2019). Mobile technologies and applications for the internet of things. In M. E. Auer \& T. Tsiatsos (Eds.), Mobile Technologies and Applications for the Internet of Things (IMCL), Advances in Intelligent Systems and Computing (Vol. 909, pp. 204-211). Springer, Cham. https://doi.org/10.1007/978-3-030-11434-3

Deterding, S., Dixon, D., Khaled, R., \& Nacke, L. (2011). From game design elements to gamefulness: Defining "gamification." In A. Lugmayr, H. Franssila, C. Safran, \& I. Hammouda (Eds.), MindTrek '11: Proceedings of the 15th International Academic MindTrek Conference: Envisioning Future Media Environments (pp. 9-15). The Association for Computing Machinery, Inc. https://doi.org/10.1016/s0022-5347(11)60242-5

Dörnyei, Z., \& Taguchi, T. (2010). Questionnaires in second language research: Construction, administration, and processing. (2nd ed.). Routledge.

Esteves, M., Pereira, A., Veiga, N., Vasco, R., \& Veiga, A. (2017). The use of new learning technologies in higher education classroom: a case study. In M. E. Auer, D. Guralnick, \& I. Simonics (Eds.), Teaching and Learning in a Digital World, International Conference on Interactive Collaborative Learning (Vol. 1, pp. 499-506). Springer, Cham. https://doi.org/10.1007 978-3-31973210-7

Felszeghy, S., Pasonen-Seppänen, S., Koskela, A., Nieminen, P., Härkönen, K., Paldanius, K. M. A., Gabbouj, S., Ketola, K., Hiltunen, M., Lundin, M., Haapaniemi, T., Sointu, E., Bauman, E. B., Gilbert, G. E., Morton, D., \& Mahonen, A. (2019). Using online game-based platforms to improve student performance and engagement in histology teaching. $B M C$ Medical Education, 19(1), 1-11. https://doi.org/10.1186/s12909-019-1701-0

Fraenkel, J. R., Wallen, Norman, E., \& Hyun, H. H. (2012). How to design and evaluate research in education (8th ed.). McGraw Hill.

Gani, A. F. A., Hassim, A. R. A., \& Mohandas, E. S. (2016). Students' perceptions of new web 2.0 tools' usage in classroom instruction. In J. E. Luaran, A. S. Anaelka., \& N. A. Alias (Eds.), Envisioning the Future of Online Learning (pp. 247-257). Springer, Singapore. https://doi.org/10.1007/978-981-100954-9

Georgieva, E. S., Smrikarov, A. S., \& Georgiev, T. S. (2011). Evaluation of mobile learning system. Procedia Computer Science, 3, 632-637. https://doi.org/10.1016/.procs.2010.12.106

Ghorbani, N., \& Ebadi, S. (2020). Exploring learners' grammatical development in mobile assisted language learning. Cogent Education, 7(1), 1-14. https://doi.org/10.1080/2331186X.2019.1704599

Journal on English as a Foreign Language, 10(2), 246-267

p-ISSN 2088-1657; e-ISSN 2502-6615 
Guardia, J. J., Del Olmo, J. L., Roa, I., \& Berlanga, V. (2019). Innovation in the teaching-learning process: The case of Kahoot! On the Horizon, 27(1), 3545. https://doi.org/10.1108/OTH-11-2018-0035

Hadijah, H., Pratolo, B. W., \& Rondiyah, R. (2020). Interactive game "Kahoot!" as the media of students' vocabulary. Journal on English as a Foreign Language (JEFL), 10(1), 87-105. https://doi.org/10.23971 ßefl.v10i1.1670

Heflin, H., Shewmaker, J., \& Nguyen, J. (2017). Impact of mobile technology on student attitudes, engagement, and learning. Computers and Education, 107, 91-99. https://doi.org/10.1016/.compedu.2017.01.006

Hou, Y. (2018). Integration of Kahoot into EFL classroom. In C. Stephanidis (Ed.), 20th International Conference - HCI International 2018 (Issue 2016, pp. 404-409). Springer International Publishing. https://doi.org/10.1007 9783-319-92285-0

Hsu, L. (2013). English as a foreign language learners' perception of mobile assisted language learning: A cross-national study. Computer Assisted Language Learning, 26(3), 197-213. https://doi.org/10.1080/09588221.2011.649485

Huang, B., Hew, K. F., \& Lo, C. K. (2018). Investigating the effects of gamification-enhanced flipped learning on undergraduate students' behavioral and cognitive engagement. Interactive Learning Environments, 27(8), 1-21. https://doi.org/10.1080/10494820.2018.1495653

Hughes, E. S., Bradford, J., \& Likens, C. (2018). Facilitating collaboration, communication, and critical thinking skills in physical therapy education through technology-enhanced instruction: A case study. TechTrends, 62(3), 296-302. https://doi.org/10.1007/s11528-018-0259-8

Hwang, W. Y., Shih, T. K., Ma, Z. H., Shadiev, R., \& Chen, S. Y. (2015). Evaluating listening and speaking skills in a mobile game-based learning environment with situational contexts. Computer Assisted Language Learning, 29(4), 639-657. https://doi.org/10.1080/09588221.2015.1016438

Ismail, M. A., Ahmad, A., Mohammad, J. A., Fakri, N. M. R. M., Nor, M. Z. M., \& Pa, M. N. M. (2019). Using Kahoot! as a formative assessment tool in medical education: A phenomenological study. BMC Medical Education, 19, 1-8. https://doi.org/10.1186/s12909-019-1658-z

Jones, S. M., Katyal, P., Xie, X., Nicolas, M. P., Leung, E. M., Noland, D. M., \& Montclare, J. K. (2019). A “KAHOOT!” approach: The effectiveness of game-based learning for an advanced placement Biology class. Simulation and Gaming, 50(6), 832-847. https://doi.org/10.1177/1046878119882048

Kinder, F. D. A., \& Kurz, J. M. (2018). Gaming strategies in Nursing education. Teaching and Learning in Nursing, 13(4), 212-214. 
https://doi.org/10.1016/h.teln.2018.05.001

Klimova, B., \& Kacetl, J. (2018). Computer game-based foreign language learning: Its benefits and limitations. In S. K. S. Cheung, J. Lam, K. C. Li, O. Au, W. W. K. Ma, \& W. S. Ho (Eds.), Technology in Education. Innovative Solutions and Practices, ICTE 2018. (pp. 26-34). Springer Singapore. https://doi.org/10.1007/978-981-13-0008-0

Koivisto, J., \& Hamari, J. (2014). Demographic differences in perceived benefits from gamification. Computers in Human Behavior, 35, 179-188. https://doi.org/10.1016/j.chb.2014.03.007

Kukulska-Hulme, A., \& Viberg, O. (2018). Mobile collaborative language learning: State of the art. British Journal of Educational Technology, 49(2), 207-218. https://doi.org/10.1111/bjet.12580

Kumar, B. A., \& Chand, S. S. (2019). Mobile learning adoption: A systematic review. Education and Information Technologies, 24(1), 471-487. https://doi.org/10.1007/s10639-018-9783-6

Lauermann, V., \& Barbosa, D. N. F. (2018). Digital technologies applied to textual reading and understanding in English: A practical approach using Kahoot. In L. Uden, D. Liberona, \& J. Ristvej (Eds.), 7th International Workshop, Learning Technology for Education Challenges (LTEC) (pp. 70-79). Springer, Cham. https://doi.org/10.1007 978-3-319-95522-3

Lee, C. C., Hao, Y., Lee, K. S., Sim, S. C., \& Huang, C. C. (2019). Investigation of the effects of an online instant response system on students in a middle school of a rural area. Computers in Human Behavior, 95, 217-223. https://doi.org/10.1016/).chb.2018.11.034

Lee, C., Yeung, A. S., \& Ip, T. (2016). Use of computer technology for English language learning: Do learning styles, gender, and age matter? Computer Assisted Language Learning, 29(5), 1033-1049. https://doi.org/10.1080/09588221.2016.1140655

Licorish, S. A., Owen, H. E., Daniel, B., \& George, J. L. (2018). Students' perception of Kahoot!'s influence on teaching and learning. Research and Practice in Technology Enhanced Learinng, 13(9), 1-23. https://doi.org/10.1186/s41039-018-0078-8

Lin, C.-C., Lin, V., Liu, G.-Z., Kou, X., Kulikova, A., \& Lin, W. (2019). Mobileassisted reading development: A review from the Activity Theory perspective. Computer Assisted Language Learning, 1-32. https://doi.org/10.1080/09588221.2019.1594919

Lin, J.-J., \& Lin, H. (2019). Mobile-assisted ESL/EFL vocabulary Learning: A systematic review and meta-analysis. Computer Assisted Language Learning, 32(8), 878-919. https://doi.org/10.1080/09588221.2018.1541359 
Liu, T. Y., \& Chu, Y. L. (2010). Using ubiquitous games in an English listening and speaking course: Impact on learning outcomes and motivation. Computers and Education, 55(2), 630-643. https://doi.org/10.1016/.compedu.2010.02.023

Luís, A. R. (2018). Perceptions of the educational benefits of mobile devices in language teaching and learning. In R. Álvaro, H. Adeli, L. P. Reis, \& S. Costanzo (Eds.), World Conference on Information Systems and Technologies (Vol. 1, pp. 1406-1415). Springer International Publishing. https://doi.org/10.1007/978-3-319-77712-2

Ma, Q. (2017). A multi-case study of university students' language-learning experience mediated by mobile technologies: A socio-cultural perspective. Computer Assisted Language Learning, 30(3-4), 183-203. https://doi.org/10.1080/09588221.2017.1301957

Mahdi, H. S. (2017). Effectiveness of mobile devices on vocabulary learning: A meta-analysis. Journal of Educational Computing Research, 56(1), 134-154. https://doi.org/10.1177/0735633117698826

Manfreda, K. L., \& Vehovar, V. (2008). Internet survey. In E. D. de Leeuw, J. J. Hox, \& D. A. Dillman (Eds.), International Handbook of Survey Methodology (pp. 264-284). Lawrence Erlbaum Associates, Taylor \& Francis Group.

Martins, E. R., Geraldes, W. B., Afonseca, U. R., \& Gouveia, L. M. B. (2019). Using Kahoot as a learning tool. In I. Ramos, R. Quaresma, P. Silva, \& T. Oliveira (Eds.), Information Systems for Industry 4.0. Lecture Notes in Information Systems and Organisation (pp. 161-169). Springer Nature Switzerland AG. https://doi.org/10.1007 /978-3-030-14850-8_11

$\mathrm{Mu}, \mathrm{H}$. , \& Paparas, D. (2015). Incorporating the advantages of clickers and mobile devices to teach Economics to non-economists. Cogent Economics and Finance, 3(1), 1-10. https://doi.org/10.1080/23322039.2015.1099802

Murphy, M. P. A. (2018). "Blending" Docent Learning: Using Google Forms Quizzes to Increase Efficiency in Interpreter Education at Fort Henry. Journal of Museum Education, 43(1), 47-54. https://doi.org/10.1080/10598650.2017.1396435

Ou-Yang, F. C., \& Wu, W. C. V. (2017). Using mixed-modality vocabulary learning on mobile devices: Design and evaluation. Journal of Educational Computing Research, 54(8), 1043-1069. https://doi.org/10.1177/0735633116648170

Pereira, R. C. S., Dinis, M. A. P., \& Gouveia, L. Bo. (2019). The use of mobile devices in environmental education. In W. L. Filho, U. Tortato, \& F. Frankenberger (Eds.), Universities and Sustainable Communities: Meeting the Goals of the Agenda 2030. World Sustainability Series. (pp. 643-649).

Journal on English as a Foreign Language, 10(2), 246-267

p-ISSN 2088-1657; e-ISSN 2502-6615 
Springer, Cham. https://doi.org/10.18844/gjhss.v3i3.1521

Persico, D., Passarelli, M., Dagnino, F., Manganello, F., Earp, J., \& Pozzi, F. (2019). Games and learning: Potential and limitations from the players' point of view. In A. Liapis, G. N. Yannakakis, M. Gentile, \& M. Ninaus (Eds.), 8th International Conference on Games and Learning Alliance (pp. 134145). Springer Cham. https://doi.org/10.1007 /978-3-030-11548-7

Plump, C. M., \& LaRosa, J. (2017). Using Kahoot! in the classroom to create engagement and active learning: A game-based technology solution for elearning novices. Management Teaching Review, 2(2), 151-158. https://doi.org/10.1177/2379298116689783

Prensky, M. (2001a). Digital native and digital immigrant part 1. On the Horizon, 9(5), 1-6. https://doi.org/10.1108/10748120110424816

Prensky, M. (2001b). Digital natives, digital immigrants part 2: Do they really think differently? On the Horizon, 9(6), 1-6. https://doi.org/10.1093/ae/59.4.194

Rahman, R. A., Ahmad, S., \& Hashim, U. R. (2018). The effectiveness of gamification technique for higher education students engagement in polytechnic Muadzam Shah Pahang, Malaysia. International Journal of Educational Technology in Higher Education, 15(41), 1-16. https://doi.org/10.1186/s41239-018-0123-0

Şad, S. N., \& Göktaş, Ö. (2014). Preservice teachers' perceptions about using mobile phones and laptops in education as mobile learning tools. British Journal of Educational Technology, 45(4), 606-618. https://doi.org/10.1111 bjet.12064

Sailer, M., \& Homner, L. (2020). The gamification of learning: A meta-analysis. Educational Psychology Review, 32, 77-112. https://doi.org/https://doi.org/10.1007/s10648-019-09498-w

Tan, C., \& Liu, M. (2016). Using ICT in teaching the Chinese language: Practices and reflections from Singapore. In K. Soh (Ed.), Teaching Chinese Language in Singapore: Retrospect and Challenges (pp. 45-65). Springer, Singapore. https://doi.org/10.1007 /978-981-10-0123-9_10

Tsihouridis, C., Vavougios, D., \& Ioannidis, G. S. (2018). Assessing the learning process playing with Kahoot - A study with upper secondary school pupils learning electrical circuits. In M. E. Auer, D. Guralnick, \& I. Simonics (Eds.), Teaching and Learning in a Digital World. ICL 2017. Advances in Intelligent Systems and Computing (pp. 602-612). Springer, Cham. https://doi.org/10.1007 /978-3-319-73210-7

Uz Bilgin, C., \& Tokel, S. T. (2019). Facilitating contextual vocabulary learning in a mobile-supported situated learning environment. Journal of 
Educational Computing Research, 57(4), 930-953. https://doi.org/10.1177/0735633118779397

$\mathrm{Vu}$, P. H., \& Hoffman, J. (2011). Using online surveys in Vietnam: An exploratory study. International Journal of Market Research, 53(1), 41-62. https://doi.org/10.2501/1JMR-53-1-041-062

Wang, A. I. (2015). The wear out effect of a game-based student response system. Computers and Education, 82, 217-227. https://doi.org/10.1016/j.compedu.2014.11.004

Wang, A. I., \& Lieberoth, A. (2016). The effect of points and audio on concentration, engagement, enjoyment, learning, motivation, and classroom dynamics using Kahoot! In T. Connolly \& L. Boyle (Eds.), The 10th European Conference of Game based Learning (Issue October, pp. 737748). Academic Conferences and Publishing International Limited.

Wang, A. I., \& Tahir, R. (2020). The effect of using Kahoot! for learning - A literature review. Computers and Education, 149, 1-22. https://doi.org/10.1016/.compedu.2020.103818

Wang, J.-T., Hung, L.-C., Hsieh, H.-M., Tsai, J.-T., \& Lin, I.-H. (2012). Computer technology integration and multimedia application for teacher professional development: The use of instructional technology in the classroom settings. In G. Lee (Ed.), IERI Procedia (Vol. 2, pp. 616-622). Elsevier. https://doi.org/10.1016/j.ieri.2012.06.143

Yıldırım, İ., \& Şen, S. (2019). The effects of gamification on students' academic achievement: A meta-analysis study. Interactive Learning Environments, 118. https://doi.org/10.1080/10494820.2019.1636089

Zarzycka-piskorz, E. (2016). Kahoot it or not? Can games be motivating in learning grammar? Teaching English with Technology, 16(3), 17-36. https://eric.ed.gov /?id=EJ1135685

Zhonggen, Y., Ying, Z., Zhichun, Y., \& Wentao, C. (2019). Student satisfaction, learning outcomes, and cognitive loads with a mobile learning platform. Computer Assisted Language Learning, 32(4), 323-341. https://doi.org/10.1080/09588221.2018.1517093

\section{Author's Brief CV}

Moh. Arif Mahbub is a lecturer at the English Education Department, Faculty of Teacher Training and Education, Universitas Islam Jember, Jawa Timur, Indonesia. His research interests include ESP, ELT Media, MALL, and Digital Game-Based Learning (DGBL).

Journal on English as a Foreign Language, 10(2), 246-267

p-ISSN 2088-1657; e-ISSN 2502-6615 